\title{
Verduisterde selfinsig as morele probleem
}

\author{
J.H. van Wyk \\ Departement Dogmatologie en Ekklesiologie \\ Potchefstroomse Universiteit vir $\mathrm{CHO}$ \\ POTCHEFSTROOM
}

\begin{abstract}
Obscured self-perception as moral problem

In this article the cause, the effect and the solution of an obscured self-perception are investigated. The canse of an obscured self-perception is to be found imbedded in man's problematic relation to God, a reality which affects every aspect of human life. These effects can be perceived in the fields of marriage and sexual life. but also in politics and ecomomics. The solution of all human problems can only be found in the gospel of Christ, yes, in Christ Himself.
\end{abstract}

\section{Inleiding}

Dit is al so 'n gemeenplaas om te sê dat ons in Suid-Afrika in 'n moraliteitskrisis verkeer dat hieroor nie verder uitgebrei hoef te word nie. Miskien moet ons byvoeg dat die huidige krisis méér omvat as 'n moraliteitskrisis - dit is 'n krisis wat ons totale lewe in al sy fasette raak (waarvan moraliteit maar een aspek is). Hierdie krisis raak ons verhouding tot God, tot ons medemens, tot onsself en tot die natuur/omgewing, almal aspekte wat tans tereg onder die soeklig kom. Dis haas onnodig om daaraan te herinner dat hierdie verhoudings, ofskoon dit van mekaar onderskei kan word, nooit geskei mag word nie en 'n onlosmaaklike eenheid vorm. Ek sal dus genoodsaak wees om, bykomend tot die toespitsing op die self, af en toe ook die ander verhoudings aan te raak, omdat die mens se verduisterde selfinsig ook ' $n$ invloed op al hierdie verhoudings het.

Ek stel my ten doel om eerstens te kyk na die oorsaak van die mens se verduisterde selfinsig, tweedens op die effek daarvan en derdens op 'n uitweg daaruit.

\section{Die oorsaak van die verduisterde selfinsig}

Die vraag kan met reg gestel word waar die mens se verduisterde insig ten opsigte van homself vandaan kom en hoe hy daarvan kennis kan bekom. Baie mense het tewens geen besef van hoe verduister hulle in hulleself is nie en hulle meen dat hulle met hulle gesonde menslike verstand, met 'n bietjie lewenservaring, met 'n goeie opvoeding, met wetenskaplike en tegmologiese 
prestasies so ongeveer alle probleme op aarde - en in Suid-Afrika - sal kan oplos. Helaas is dit nie moontlik nie. Ons sal dieper moet delf.

Die inleidingsin van een van die beroemdste boeke wat ooit geskryf is, lui soos volg: "Byna die volle eindtotaal van ons wysheid, wat ons as die ware en grondige wysheid moet beskou, bestaan uit twee dele: kennis van God en kennis van onsself' (Calvyn, Institusie, 1.1.1). In die Franse vertaling van 1560 lui dit: "In ons ken(-nis) van God, ken elkeen van ons ook onsself".

Hiermee wil Calvyn (1.15.1) sê dat ons onsself nie kan ken as ons God nie ken nie - en omgekeerd. Die mens is immers in die allemouste verhouding tot God geskape, hy is beeld van God. Daarom is dit onmoontlik om die mens los van sy verhouding tot God te probeer verstaan. Ons Godskennis is van fundamentele betekenis vir ons mensekennis (Jes. 6:5). "Sê my wie jou God is en ek sal jou sê wie jy is," het iemand tereg opgemerk.

Die mens wat homself sien as mens-van-God en mens-voor-God, kan homself nie anders sien as sondaar-voor-God nie. Selfkennis begin met sondekennis (Calvyn, $1.15 .1 ; 2.1 .4-5$ ). Die mens het van God vervreem en het sy eie koers gegaan met al die negatiewe gevolge daaraan verbonde.

Ten einde die sonde van die mens te tipeer is verskillende woorde al gebruik woorde soos hoogmoed (Augustinus), ongeloof (Calvyn, Luther), ongehoorsaamheid (Calvyn), liefdeloosheid, wetteloosheid, verveemding. In die Reformatoriese belydenisskrifte word in hierdie verband harde taal gebruik: Die mens is van nature geneig om God en sy naaste te haat (HK 2:5) en hy is glad nie in staat om iets goeds (tot saligheid) te doen nie en is geneig tot alle kwaad tensy God ingryp (HK 3:8).

Menslike sonde gaan dus veel dieper as om te fouteer en te faal, sonde impliseer meer as tekortkomings en beperkthede, want dit sê dat die mens se verhouding tot God versteur is. Die mens wou - en wil - "soos God wees"; hy wil uit homself uitmaak wat die onderskeid tussen goed en kwaad is (Gen. 3:5); hy wil outonoom wees.

Hierdie opstand teen God en ongehoorsaamheid aan die Woord van God waaier in alle windrigtings uit. Dit bring onmiddellik 'n versteurde verhouding met sy medemens mee (Kain slaan vir Abel dood, Gen. 4) en loop uit op uitbuiting van die natuur. Die sonde gryp wyd om hom heen, versteur alle verhoudings, besmet alle intensies en benadeel alle dade.

Die verduisterde selfinsig van die mens hang saam met die verduisterde siening van God. Waar die verhouding met God skeefloop, loop alle ander verhoudings skeef. Luther $(1965: 24,71,72)$ het tereg opgemerk dat alle ontsporings begin 
met 'n oortreding van die eerste gebod. "As God nie bestaan nie, is alles geoorloof' (Dostojewski).

Ons het pas opgemerk dat waar die verhouding met God skeefloop, alle ander verhoudings skeefloop en ons sou verwag dat die omgekeerde hiervan ook waar sou wees, naamlik dat as die verhouding met God herstel is, alle ander verhoudings ook behoort te herstel. Tog sit ons in Suid-Afrika met die verbysterende situasie dat $77 \%$ van die bevolking hulleself Christene noem (dit wil sê mense met 'n herstelde verhouding tot God), terwyl die moraliteitskrisis in die land hand oor hand toeneem. Hoe is dit moontlik? Het ons te doen met 'n soutlose Christendom? Is die bose magte magtiger as Christus? 'n Mens sou immers verwag dat 'n land met soveel Christene byna in staat sou wees om 'n paradys op aarde te skep!

\section{Die effek van die verduisterde selfinsig}

Prinsipieel benader, is dit korrek om te sê dat die van God losgeraakte mens homself nie ten volle en reg kan ken nie. Die sonde het 'n verduisterende effek op die mens. Ons vind by die sondige mens 'n selfsentrisme, ' $n$ ingekeerdheid in homself (incurvatus in se, vgl. Luther, 1965:66), maar verder ook 'n baasspelerigheid wat hom op baie lewensterreine laat geld. Outonomisme, rasionalisme, individualisme en egoïsme het die hoofkenmerke van die moderne (veral Westerse) mens geword. Redelikheid word met sedelikheid geidentifiseer. Die menslike verstand moet nie meer deur die evangelie genonneer word nie, maar moet vry wees om sélf uit te maak wat goed is en wat kwaad.

Veral sedert die agtiende eeu, met die opkoms van die Verligting, word daar van die outonome mens gepraat, die mens wat sy verstand moet gebruik (Kant), die mens wat God nie meer nodig het nie, ook nie om die gate en leemtes van sy menslike bestaan te vul nie (vgl. Bonhoeffer, 1968:121). Daar word beweer dat die God wat gapings vul, dood is. Die skreiende ironie is egter dat hoe magtiger die mens word, hoe magteloser word hy (Van Riessen, 1967:42, 120). Die mense wat vandag leef, is immers die eerste geslag mense wat daartoe in staat is om alle lewe op aarde met behulp van kernwapens uit te wis. Daarom moet dit toegejuig word dat Suid-Afrika in 1991 die kernsperverdrag onderteken het om sodoende 'n bydrae te lewer om Afrika 'n kernwapenvrye kontinent te probeer maak.

Die vergoddeliking van die mens beteken - ironies - die ontmensliking van die mens. Anders gesê, die deifikasie (vergoddeliking) van die mens loop uit op die reïfikasie (verdingliking) van die mens.

Laat ons egter meer konkreet aandag gee aan die gevolge van die selfverduistering wat daar by die mens ingetree het. 


\section{- Huweliksmoraal}

Die outonome en egoïstiese mens laat hom orals geld. In die huweliksmoraal het dit funeste gevolge en lewer dit 'n deurslaggewende bydrae tot die opbreek van die gesins- en familielewe.

\section{- Politieke moraal}

Op die terrein van die politieke moraal word dit sigbaar as imperialisme, wat in Suid-Afrika talle swart en wit vorms aangeneem het. Die laaste halfeeu het ons daarmee te doen gekry in die vorm van apartisme, waar 'n minderheid die mag verower en beoefen het ten koste van die vryheid van ander. Die probleem is egter dat sonde ' $n$ mens so verblind - en verduister - dat die sonde nie as sonde gesien word nie. Ons het nie besef dat ons op die terrein van die politieke moraal al vir dekades lank met 'n duiselingwekkende krisis te doen het wat die hele samelewing in al sy geledinge geïnfiltreer en geinfekteer het nie. Langsamerhand het die besef egter deurgebreek dat die apartheidsmodel wat ons as Afrikaners in Suid-Afrika probeer toepas het - seker met goeie bedoelings - 'n onregverdige en uitbuitende model was. Die nuwe handves van menseregte sal hierin 'n korrigerende invloed uitoefen. As Christene mag ons vir die idee van menseregte nie terugskrik nie, die inhoud daarvan kan immers ook vanuit die Christelike etiek medebepaal word; daarby bied dit beskerming teen staatsabsolutisme en uitbuiting van mekaar.

Machiavelli se standpunt dat dit vir owerhede vernietigend sal wees om die Christelike moraal na te volg en dat politiek en moraliteit sover moontlik geskei moet word, is vir die politieke etiek 'n selfverwoestende vertrekpunt en daarom volkome onaanvaarbaar.

\section{- Ekonomiese moraal}

Op die terrein van die ekonomiese moraal openbaar die outonome mens hom as individualis en kapitalis wat die vryemark-ekonomie soveel vryheid laat dat dit alle verantwoordelikheid teenoor die (veral arm) naaste vergeet. Die selfgesentreerde mens is op selfsug, selfverryking, selfoorskatting en selfhandhawing ingestel en hy vergeet dat hy rentmeester op aarde is wat sy arm naaste met raad en daad moet bystaan. In Suid-Afrika, met sy paar miljoen werkloses en sy groot armoede, wag daar vir Christene 'n baie groot taak. Christene moet nougeset waak teen materialisme en geldgierigheid wat die wortel is van alle kwaad (1 Tim. 6:10). Dink net aan die talle korrupsies van verskeie staatsdepartemente wat die afgelope jare aan die lig gekom het. Is daar werklik minder korrupsie in Suid-Afrika as in die res van Afrika? Ons is ook byna nie meer in staat om welsynsdienste en liefdadigheid te verrig sonder dat dit een of ander vorn van dobbelary aanneem nie. Selfsug en selfverryking is ondeugde wat deur die Christelike etiek veroordeel word. In hierdie verband kan die Afrika-Christene, met hulle beklemtoning van gemeenskap en mededeelsaamheid, 'n belangrike 
inset lewer. Die Afrika-etiek staan hier direk teenoor die Westerse etiek van individualisme en selfsug - al moet dadelik bygevoeg word dat die arbeidsetiek van Afrika op talle punte gekorrigeer behoort te word. In Venda is daar 'n gesegde wat lui dat - in geval van nood - die kinders van een pa selfs die kop van 'n sprinkaan onder mekaar moet verdeel.

\section{- Seksuele moraal}

Op die terrein van seksuele moraal openbaar die outonome mens hom as die sekslustige wat op maksimale genot ingestel is (hedonisme). Genot neem die plek in van God (2 Tim. 3:4). Weliswaar het die opkoms van vigs 'n remmende effek op die seksuele rewolusie, maar dit is nog hoegenaamd nie gestuit nie. Dink maar net aan die afmetings wat huweliksverbrokkeling, kindermolestering en pornografie in ons samelewing aanneem. Seksualiteit sonder liefde is selfsugtig.

\section{- Is selfliefde verkeerd?}

Dit alles bring ons voor die vraag te staan of selfliefde dan verkeerd is. Egoïsme en selfsentrisme moet ons afwys, maar moet ons daarmee saam ook selfliefde en selfhandhawing die deur wys? Mag die mens hom nie self handhaaf nie? Mag 'n mens homself dan nie liefhê nie? Vorm dit nie 'n deel van die groot liefdesgebod, naamlik Godsliefde, naasteliefde én selfliefde nie?

Daar is sommige teoloë wat van mening is dat selfliefde ' $n$ derde gebod is en dat 'n mens jouself móét liefhê. Die mees aanvaarbare verklaring van die Bybel is dat die mens homself mág liefhê en nie dat hy homself móét liefhê nie. Die mens het homself van nature lief en sy probleem was nog altyd dat hy te véél selfliefde openbaar en te mín naasteliefde, dat hy te véél sy eiebelang soek en te min dié van sy naaste bevorder (vgl. 1 Kor. 13:5; 10:24, 33; Fil. 2:5-8). Oordrewe selfliefde is ' $n$ teken van verwording ( 2 Tim. 3:2). Die sonde maak ons meer selfsentries as medemenslik; daarom ag die Bybel selfverloëning so belangrik (Fil. 2:5 e.v.), terwyl dit geen goeie woord oor selfhandhawing sê nie. Nee, 'n mens moet jouself nie vernietig en verinneweer nie, jy het ook 'n verantwoordelikheid teenoor jouself, maar dan mag dit nooit geskied ten koste van jou naaste nie. Jy moet aan ander doen wat jy aan jouself gedoen wil hê (Matt. 7:12). Dit geld sowel vir die individuele as vir die sosiale lewe.

In 'n sekere sin radikaliseer Christus die gebod tot naasteliefde en sê Hy dat ons ons naaste méér moet liefhê as onsself: "Niemand het groter liefde as dit: dat hy sy lewe vir sy vriende afle" (Joh. 15:13). Christus gee 'n nuwe gebod: "Soos Ek julle liefhet, moet julle mekaar liefhê" (Joh. 13:34, 15:13). Christelike liefde is 'n liefde tot die dood.

Een van die grootste probleme in Suid-Afrika is dat daar te veel liefde vir die self en die eie groep is - wit teenoor wit, en swart teenoor swart - en dat ons veels te 
min die ander mens, selfs die vyand, in die visier kry, dit wil sê in liefde na hom uitreik.

Wie homself bevoordeel ten koste van sy naaste, grawe sy eie graf en werk mee aan sy eie ondergang. "Waar die self van die mens sentraal staan, is die trappe van vergelyking: handhaaf - gehawend - haweloos" (Rossouw, 1981:107). Die edelste vorm van selfhandhawing is selfverloëning - ook in die politiek! Want wie die wêreld wen, verloor homself.

\section{Die weg van bevryding}

Die vraag is hoe ons uit die impasse kan kom. Om dié doel te bereik moet ons by die begin begin. Ons moet by God begin.

Dit is alleen die Here God wat deur sy Gees harde harte kan oopbreek om weer ander mense as medemense raak te sien, as mense geskape na die beeld van God. Hoe totaal verkeerd is daardie blankes tog nie wat swart mense as onmense sien. Die evangelie van Christus vertel ons van ons groot bevryding uit die mag van die sonde en maak ons vry om ook ons geknelde en verontregte naaste te hulp te snel. Die evangelie breek die harde kors van selfsentrisme oop en ontsluit ons vir ons medemens. Liefde, ook vyandsliefde, is die geheim van die lewe. Haat en vrees breek 'n samelewing stukkend en geen samelewing kan daarop gebou word nie.

Ons het in die begin genoem dat ons in Suid-Afrika in die besonder gunstige situasie verkeer dat ongeveer $77 \%$ van die bevolking hulle as Christene beskou, maar dat ons desondanks in 'n moraliteitskrisis vasgevang sit. 'n Mens sou so verwag dat wanneer sóveel mense die evangelie van vrede aanvaar het, daar in so ' $n$ land die allerbeste menseverhoudings en morele standaarde sou heers en dat daar 'n situasie van volkome politieke rus sou wees. Waarom is dit nie die geval nie? Het die Christendom hier gefaal? Is ons almal ideologies verblind? Sal dit nie een van die grootste skandes in die kerkgeskiedenis wees indien 'n land met soveel Christelike potensiaal in vlamme moet opgaan nie?

Een van die groot redes waarom die kerke in Suid-Afrika nie 'n groter bydrae ten opsigte van die morele en samelewingsvraagstukke kon lewer nie, is vanweë die kerklike verdeeldheid en kerklike intrcvertisme. Die wit en swart, die Engelse en Afrikaanse kerke is hopeloos te verdeeld, ook wat hulle siening ten opsigte van die Suid-Afrikaanse morele problematiek betref, om werklik bevrydend te funksioneer. Hulle is almal veels te veel ideologies vasgevang in die "wit saak" (blanke mag) en die "swart saak" (swart bevryding). In plaas van 'n kritiese solidariteit vind ons 'n reserwelose aanvaarding van die eie.

Ons sal almal 'n groter bereidheid moet openbaar om veel meer vanuit die evangelie van versoening te leef. Die evangelie laat ons onsself sien soos ons is: 
sondaars voor God en uitbuiters van ons naaste. Die evangelie maak 'n mens ootmoedig - die mens kan hom immers nie self verlos nie maar moet verlos wórd - en bring hom tot skuldbelydenis. Die evangelie breek die mens oop. Daar is weinig dinge so bevrydend as skuldbelydenis, ook politieke skuldbelydenis. Juis in 'n tyd dat selfverontskuldiging aan die orde van die dag is en politieke partye van die metode van blamering (van die ander) byna 'n nasionale sport gemaak het, kan ware skuldbesef - wat iets anders is as 'n skuldkompleks - werklik 'n bevrydende uitwerking hê. Die openbare skuldbelydenis wat W.D. Jonker (1991:92) in 1990 te Rustenburg gemaak het, was nie voorbarig nie maar tiperend van 'n Christelike lewenshouding (Jak. 5:16). Bybels gesien, is dit nie ongehoord vir iemand om huidige en vorige sondes, eie en voorvadersondes te bely nie (Lev. 26:40; Eks. 32:32; Neh. 1:6, 9:2; Dan. 9:4-5, 20). So 'n skuldbelydenis kan nog 'n groter effek hê en meer bevrydend werk indien 'n staatspresident as staatshoof so 'n belydenis sou uitspreek. So 'n uitspraak sal geen teken van swakheid en abdikasie wees nie maar juis 'n teken van geestelike krag en volwassenheid. Dit behoort ook nie moeilik te wees nie aangesien twee van die Afrikaanse kerke hulle reeds krities oor apartheid uitgelaat het. Sinode 1991 van die GKSA het erken dat die ideologie van apartheid sonde is en die Bybelse regverdiging daarvan 'n dwaling (Acta 1991:160/187). Ook die Nederduitse Gereformeerde Kerk het hom krities oor apartheid uitgelaat (Kerk en samelewing, 1990:5.2).

Skuldbelydenis vra natuurlik om vergifnis. Vergifnis word nie geskenk op grond van skuldbelydenis nie - soos die Bevrydingsteologie wil - maar dit vind ook nie plaas sonder belydenis nie. Die wit skuldbelydenis vra om swart vergifnis en om 'n gesámentlike voortgang. Daar sal voortaan veel meer komınunikasie tussen wit en swart Christene moet plaasvind ten einde die eise van die evangelie vir ons vaderland uit te spel. Die model van konfrontasie moet omskep word in 'n model van kommunikasie, nie net omdat dit so tiperend is van die Afrikakultuur nie, maar omdat die evangelie dit van ons eis.

Ons swart landgenote moet uiters bedag wees op die motief van selfverontskuldiging deur alles wat in die land skeefloop aan apartheid te wil toeskryf. Ongetwyfeld het apartheid vele probleme geskep en baie ellende veroorsaak maar daar is ook talle ander oorsake. Selfverontskuldiging is ' $n$ tipies menslike maar sondige reaksie (Gen. 3:12-13). Dit misken immers persoonlike verantwoordelikheid en persoonlike aanspreeklikheid. Wit en swart sal voortaan sáám moet bou aan 'n kode van morele waardes vir Suid-Afrika.

Uiteindelik moet dit alles uitloop op 'n ander Suid-Afrika, op 'n getransformeerde samelewing, op ander gesindhede, ander houdings, ander metodes, ander instellings, ander sisteme, ander strukture. Dit is waar dat die hart van verandering die verandering van die hart is, maar dis nie al wat moet verander 
nie. Ook die strukture van ons samelewing moet verander, die politiek moet meer demokraties word (in die sin van 'n plurale demokrasie), die ekonomie moet meer regverdig, die samelewing moet meer vreedsaam, die omgewing moet meer bewaar word, ja, alle morele waardes moet weer hoog geag word.

Dit is opvallend dat daar tans in Suid-Afrika in 'n veel groter mate aangedring word op strukturele verandering, terwyl 'n Parlementslid uit Namibië in 1992 opgemerk het dat hulle daar ' $n$ groot behoefte het aan nuwe gesindhede. Die twee sake loop saam: persoonlike en strukturele verandering, strukturele en persoonlike verandering (Du Plessis, 1988:58). Gesindheidsveranderings, hoe onmisbaar ook al, is op sigself nie voldoende nie, en struktuurveranderings alleen, hoe belangrik ook, is ten enemale ontoereikend.

\section{Slotsom}

Waaraan ons in Suid-Afrika 'n groot behoefte het, is 'n vreedsame en regverdige samelewing, 'n samelewing waar die vrees en haat uitgeban en die selfsug oorwin is, 'n samelewing waar toegeneentheid en mededeelsaamheid heers, waar elkeen 'n werk en 'n huis het, waar die omgewing versorg word - saamgevat - 'n samelewing wat op morele waardes gevestig is en wat diensbaar is aan die voortgang van die koninkryk van God. 'n Samelewing dus wat 'n bydrae lewer tot die ontwikkeling van Afrika en 'n bate is vir die wêreldsamelewing. Daarvoor sal ons hard moet werk en daarvoor sal ons, meer as ooit tevore, moet bid.

In plaas daarvan dat mense "soos God" probeer wees en hoër wil styg as wat menslik moontlik is, moet hulle - ons! - eerder "soos Christus" word deur af te daal en te offer (Fil. 2:5 e.v.), deur te dien (Mark. 10:45) en voete te was (Joh. 13:15) en selfs vir ander te sterf (Joh. 15:13). Die navolging van Christus is nie net belangrik vir die individuele Christen en vir die kerklike gemeenskap nie, maar dit is ook vir die samelewing van ontsaglike betekenis.

Ongeveer 1600 jaar gelede het iemand in Noord-Afrika 'n boek begin skryf wat die wêreldgeskiedenis fundamenteel sou beinvloed. Dit was in 'n tyd dat die magtige Romeinse wêreldryk verkrummel en die mense begin ervaar het dat die samelewing soos 'n gebou ingeplof word. Dis toé dat die kerkvader Augustinus geskryf het oor die Stad van God en oor die twee lewenswyses, oor die lewe volgens die mens en die lewe volgens God $(14: 4 ; 15: 8)$, die lewe uit selfliefde en die lewe uit Godsliefde $(14: 13 ; 15: 3)$, die lewe in selfroem en die lewe in Godsroem (14:28). Dis toe dat hy aangetoon het dat die val van Rome toegeskryf moet word aan ... sedelike dekadensie en menslike hoogmoed! Augustinus se woorde bly hulle betekenis behou, ook vir ons vandag aan die suidpunt van Afrika. Soos in sy tyd ervaar ook ons skokkende gebeurtenisse, onder andere die verkrummeling van aardse koninkryke (ook ons eie blanke koninkryk). Dat 
sedelike dekadensie en menslike hoogmoed hierin 'n belangrike - en selfs deurslaggewende - rol gespeel het, is onbetwisbaar.

Die verbygaan van ' $n$ bepaalde fase in die geskiedenis moet ons egter nie moedeloos maak nie. Uit die bouvalle van die oue kan weer, onder die seën van God, ' $n$ nuwe samelewing verrys, met meer ootmoed, meer medemenslikheid, en meer moraliteit. En sodoende kan die samelewing meer diensbaar word aan die koms van die koninkryk van God in Suid-Afrika!

Dis ons roeping en ons taak.

\section{Verwysings}

AUGUSTINUS, A. 1983. De stad van God. Baarn : Ambo. (Vert. G. Wijdeveld.)

BONHOEFFER, D. 1968. Verzet en overgave: Brieven en aantekeninge uit de gevangenis Dietrich Bonhoeffer. Amsterdam : Ten Have.

CALVYN, J. 1984. Institusie van die Christelike godsdiens 1559. Potchefstroom : CJBF. (Vert. H.W. Simpson.)

DU PLESSIS, L. 1988. Tien perspektiewe: Gesprekke oor die toekoms. Kaapstad Tafelberg.

GKSA (Acta). 1991. Handelinge van die vier en veertigste Nasionale Sinode te Potchefstroom. Potchefstroom : Administratiewe Buro.

JONKER, W.D. 1991. Understanding the church situation and obstacles to Christian witness in South Africa. (In Alberts, L. \& Chikane, F., ed. The road to Rustenburg: The church looking forward to a new South Africa. Kaapstad : Struik. p. 87-98.)

LUTHER, M. 1965. De Grote Catechismus. Kampen : Kok. (Vert. P. Boendermaker.)

NED GEREF KERK. 1986. Kerk en samelewing: 'n Getuienis van die Ned Geref Kerk. Bloemfontein : Pro Christo.

ROSSOUW, H.W. 1981. Die sin van die lewe. Kaapstad : Tafelberg.

VAN RIESSEN, H. 1967. Mondigheid en de machten. Amsterdam : Buijten \& Schipperheijn. 
